\title{
The Value Of B2B Face-To-Face Sales Interaction In The United States, Canada And Latin America
}

Thomas J. Byrnes, (Email: byrnes@us.ibm.com), Nova Southeastern University Bahaudin G. Mujtaba, (Email: mujtaba@sbe.nova.edu), Nova Southeastern University

\begin{abstract}
Establishing and maintaining solid, long term marketing relationships are instrumental to the success of a sales representative as well as the firm the representative is employed by (Jap, 2001). This research incorporated all relevant aspects of implementing a market driven strategy to support a sustainable customer marketing relationship, including understanding face-face customer sales requirements. The ultimate goal was to understand the customer's satisfaction level with face-face sales representatives versus electronic relationship (email and telephone sales support) and as well determine if there is any greater loyalty in a face-face sales interaction versus electronic. As a result of this research, the findings indicate that customer satisfaction levels and loyalty are not compromised by engaging in an electronic relationship with the clients versus engaging in a face-face relationship. The results demonstrate that the customer satisfaction levels and loyalty are actually higher in the indirect channel versus the direct channel.
\end{abstract}

\section{INTRODUCTION}

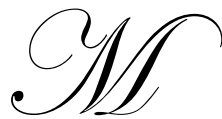

any factors have influenced the way a sales representative interfaces with his/her respective customers. Rising labor costs, innovative technology devices and evolving customer preferences are all factors that need to be considered when designing a framework for a solid marketing relationship. Establishing and maintaining solid, long term marketing relationships are vital to the success of a sales representative as well as the firm the representative is employed by (Jap 2001).

The cost of a sales call in the early 1980's was approximately $\$ 131$; those costs increased $81 \%$ from 1980 to 1985 (Kern 1986). In a 1999 Sales \& Marketing Management magazine survey, the average cost of a sales call increased 5\% from 1998 to 1999 to \$164. Another review that was done in 2001 suggested that the average business-to-business sales call had risen to $\$ 329$, according to research done by the Cahners Research (Cahners, 2001). Additionally, in 2005 it was noted that a single sales call to a potential business-to-business client cost approximately $\$ 400$ (Nickels and McHugh, 2005). All of these studies substantiate that the cost of face-face (B2B) sales calls continues to increase over time.

The research that was completed back in the 1980s was fairly thorough and further analyzed the industries where the costs were higher, for example service industry sales calls were averaging $\$ 242.24$ while industrial manufacturers were $\$ 202$. The cost per sales call vary by region as well, where the average cost per sales call in the northeast is \$197 and \$119 in the West. Further comparison reflected in this review, cited the size of the sales force also had an impact on the cost per sale call. If the company's sales force consisted of 20-49 sales reps (which reflected the lowest cost per rep), the cost would be $\$ 107$ versus the highest cost per rep which would exist in the small sales force (1-5 reps) where the cost would be $\$ 213$ (salesandmarketing online). In a contrasting study done in 1996 which was featured on the Marketing Monthly web site, the average cost of a sales call was estimated to range from $\$ 219$ to $\$ 315$, which was higher than what was previously reported (marketingmonthly online). 
Regardless of the actual cost per call, sales salaries obviously have continued to increase (salesandmarketing online). Actually face-face time in front of a customer should be decreasing as a result of all of the sales automation tools and enhanced communications that are available today. Productivity increases as a result of technology improvements have changed many jobs over the course of the last twenty years. Sales rep positions are no exception to this dynamic.

\section{THE IMPORTANCE OF SALES REP PRODUCTIVITY}

In 1988, when Sujan, Weitz \& Sujan analyzed sales productivity, they suggested that the salesperson's personal contact with a customer is most likely the most effective method of making a sale. Today, that premise might not be valid. A premise of this study is there is a need for initial face-to-face relationship building meetings with customers, but once credibility and trust is earned and established, the need for face-to-face meetings is diminished. In fact, issues can be resolved quicker, reports and information on products can be delivered immediately, product and concept demonstrations can be provided either through the web or other high speed communication facilities without having to manage scheduling challenges to ensure that the appropriate attendees are in the same place at the same time. A salesperson needs to understands their customer's likes/dislikes, budget concerns, and communication styles in order to achieve success. Since customers can vary significantly, it is extremely important to quickly assess your customer's requirements and than adapt a selling strategy that will meet those requirements. It is equally important for salespeople to maintain a repertoire of selling strategies that will match individual customer's preferences (Sujann, Weitz and Sujan 1988).

A study conducted by Dixon (2000) also provided some insight to this topic. Data was collected from 1800 large financial services sales reps. While excellent feedback was provided through the sales reps (relative to the rep's productivity); no insight was retrieved from the customer on the customer's requirements for rep visibility (Dixon 2002).

This research incorporated all relevant aspects of a market driven strategy to effectively implement a sustainable customer marketing relationship, including understanding face-face customer sales requirements.

The purpose of this research was to assess the actual customer requirements for face-face sales calls in today's environment. The intent therefore was to provide sales representatives a framework of how to best interact with their customers, specifically identifying those activities that require face-face interaction and those activities that do not require face-face interaction.

Building strong customer relationships is very important for a sales representative; in fact, buyers often have greater loyalty to salespeople than they have to the firms employing the salespeople (Anderson and Robertson 1995). Accordingly, the success of the relationship is critical for both the customer as well as the seller/sales representative.

In the Dixon study (2000) as well as market intelligence feedback that has been solicited directly from a multinational IT vendor, feedback is provided from the marketing representative's view-point. This study focused on the customer's perspective. This researcher feels strongly that while the rep's perspective is helpful, it does not provide a complete portrayal of this issue.

The sales rep wears "many hats" while interfacing with a buyer. When supply is limited and demand is greater than supply, the rep will play a production role in trying to satisfy the short-term needs of the buyer and in some instances provide recommendations either on alternative products that might have better availability or other sourcing considerations. Traditionally, in his/her sales role, the rep is there to stimulate demand for products, rather than just fulfill a customer's requirements. As a marketer, the rep needs to consider the needs of both the customer and the firm for whom they work. In a partnering role with the customer, the rep should help develop solutions that enhance the profit of both firms, whereby both firms mutually realize gain from the recommended solution (Weitz and Bradford 1999). 
Sales reps typically do not like to be forced to use "productivity tools" and so key to their acceptance is to have a group of them "pilot" various tools to determine which are the best tools to use for their industry and their product responsibility. Thus, the perception would be that sales management is not forcing the tools on them, but rather their peers have evaluated all the tools and determined which ones are the most logical for their unique environment. The philosophy that people best support the ideas they help create is inherent with this perception.

The issue that this study attempted to undertake is to fully understand the specific requirements for faceface customer sales relationships in an industrial sales setting. The scope of this effort provides a comprehensive B2B perspective including small-large business customers. For this survey, customers were categorized as follows:

Small Accounts $<100$ employees

Mid-size accounts $=100-999$ employees

Large accounts $=1000+$ employees

\section{RESEARCH QUESTION DEFINED}

The research questions were as follows:

1. As a result of technology improvements (provided through the Internet), do customers who engage in a face-face relationships with their sales reps report higher customer satisfaction than those customers that are managed electronically? Thus, the hypothesis for the customer satisfaction comparison is as follows:

H1 - Customers engaging in face-face interaction with their sales rep have greater customer satisfaction than those that engage electronically (indirect).

H1o - Customers engaging in face-face interaction with their sales rep do not have greater customer satisfaction than those that engage electronically (indirect).

H1: $\quad X_{1}>X_{2}$--where $X_{1}$ is direct (face-face interaction) and $X_{2}$ is electronic

H10: $\mathrm{X}_{1} \leq \mathrm{X}_{2}$

2. Is there any impact on "loyalty" for those customers that have a face-face relationship versus those that do not? Thus, the hypothesis for the loyalty factor is as follows:

H2 - There is greater loyalty in a face-face customer interaction than in a non face-face interaction.

H2o - There is no greater loyalty in a face-face customer interaction than in a non face-face interaction.

H2: $\quad X_{1}>X_{2}$.- where $X_{1}$ is direct loyalty response and $X_{2}$ is electronic loyalty response

H2o: $\quad X_{1} \leq X_{2}$

While the emphasis of this study prevails on business clients that were purchasing IT products and services from one multi-national vendor, the value of the results and implications extend beyond that particular scope. All organizations, profit and nonprofit, small business and large should be able to derive value from this research.

With the information available on the internet as well as the advanced communication devices (web conferencing, video conferencing, online ordering tools, etc) the traditional functions of a sales rep are changing. It is imperative that sales reps acknowledge and understand the unique requirements their customers have as it relates to the sales rep.

Truly, the sales rep needs to be acknowledged by their customers as providing "value added" services. If the rep continues to provide the same type of services delivered in the past without understanding the customer's requirements (today), they could quickly lose credibility and account control. Thus, periodically it is appropriate to evaluate the customer requirements on behalf of their sales reps to ensure a high level of customer satisfaction.

This study includes results from client's surveys $(2005$ - 2006) which were designed to evaluate the customer satisfaction levels and distinguish customers that are receiving face-face interaction, web or telephone 
support and lastly support provided through a Business Partner. It sought to understand the amount of face to face time required today versus what was required in the past.

Academic research on sales rep productivity is an important aspect to understand for individuals preparing for a sales career. Sales reps need to understand the cost of marketing to business and accordingly ensure that they are maintaining a profitable marketing relationship with the customers. Return on investment (ROI), (in this case, a sales rep's ROI) is increasingly important to all business as it attempts to deliver product to ultimate consumers. Face to face encounters represent a very expensive vehicle to communicate with customers and accordingly the value of that encounter needs to be evaluated.

As well, customers today as a result of the Internet and communication devices have extensive choices relative to whom and how they can buy products and services. Therefore, it is increasingly important to ensure that customer satisfaction is constantly monitored to ensure a high degree of loyalty with their sales reps.

\section{THE KMV MODEL AND RELATIONSHIP MARKETING}

The foundation of this study utilizes the KMV model of relationship marketing provided by Morgan and Hunt, titled "The Commitment-Trust Theory of Relationship Marketing" (Morgan 1994). This model reflects how relationship commitment and trust are impacted by the positive and negative attributes. The positive attributes include relationship benefits, shared values, communication and cooperation. The negative attributes include opportunistic behavior, relationship termination costs, acquiescence, propensity to leave, functional conflict and uncertainty. Throughout this analysis, reference to this theory will be provided. The model is reflected in Figure 1:

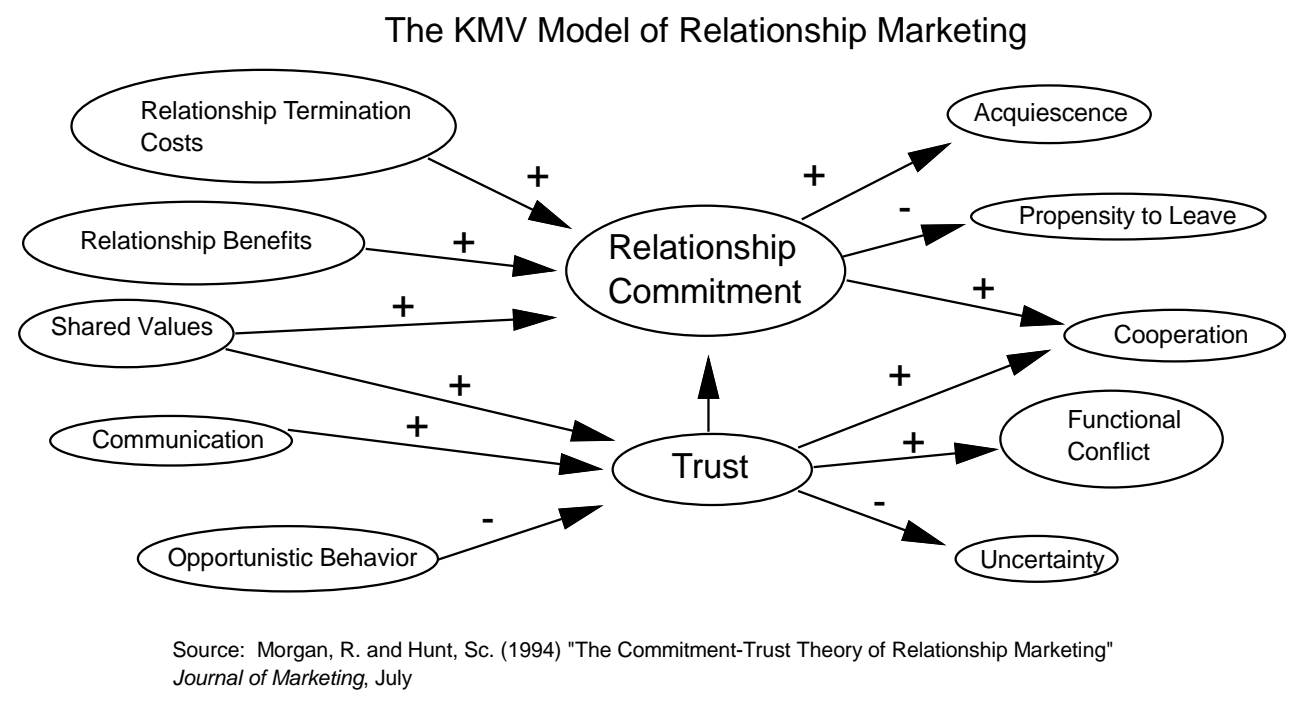

James Masciarielli suggests that there are three major components of transforming people we know into people that we know intimately. A supplier (representative or firm) must communicate with customers constantly, trust them (and be trusted by them) and provide value to them. The formula is as follows: $R=T+V+D$. That is, relationship equals trust plus value plus dialogue. (Masciarelli, 1998) He identifies five sets of skills to support his theory:

Positioning - How clearly do you convey the value that you, your team and your company bring to the table? Can you articulate a clear and lasting impression to different audiences, and do so in 30 seconds or less? 
Positioning is about knowing your values, credibility and message and being able to communicate all of this so that people understand where you're heading and what you hope to contribute. In other words, do your counterparts see you as you want them to see you?

Hunting - How well (and how often) do you create and identify new business opportunities? People with good hunting skills take the initiative to look for exactly what they want and then make plans to go after it.

Coaching - When you coach, you listen, nurture, advise and help others achieve their goals. You do whatever you can to bring out the best in people the best performance, highest commitment, and greatest results. Thus, coaching allows others to gain value from you.

Leading - If you've worked hard at the previous three items, you've earned the right to contract with others to help you achieve your objectives. Leading means motivating others to work with you to achieve your goals, it's about getting things done through others and stimulating the most effective actions for groups.

Farming - This suggests maintaining and harvesting all that value you've been creating and demonstrating. It means knowing when to tap people for the " 3 I's" introductions (to desired contacts and prospects), information (to help with your positioning and hunting) and ideas (to help with any of the other four keys). "Farmers" keep relationships current, tilling the soil for present and future value. They sow, nurture-and reap!” (Masciarelli, 1998) All of these attributes are essential elements of a solid customer relationship management system.

Another perspective provides a critical theoretical and empirical analysis of the contribution the Internet has made to successful relationship marketing. The study focuses on the positive influence that has been provided through the web, specifically its interactive structure and constant availability of information which are key variables of successful relationship marketing. (Bauer, 2002)

In this study, commitment was defined as a desire to develop a stable relationship and a confidence in the stability of the relationship. If there is commitment, the partners are willing to actively build up a stable business relationship, which diminishes the probability that the relationship be dissolved. There is positive dependence between the parties and willingness to exchange information and commitment. Additionally, opportunist behavior decreases with increasing commitment, and there is a growing interest in making joint decisions. According to Morgan/Hunt, trust exists when "one party has confidence in an exchange partner's reliability and integrity. Trust produces harmony and stability in relationships. Trust also entails constructive handling of conflicts, reduction of opportunist behavior and a reduction of transaction costs." The author noted, that although trust is based on past experience, its effects are noticed only in the future, which consequently reduces environmental complexity. Additionally, trust enhances the belief that short-term injustices will be compensated in the long run. (Bauer, 2002)

Maintaining high customer satisfaction is especially important with repeat purchases of a customer. These customers are important because they provide some stability to an organization and also provide a means of improving sales volume by increasing the size of the customer's orders (Raymond \& Turner, 1994). One study suggested that retaining an additional two to five percent of customers can improve profits greatly and works in the same manner as cutting costs by ten percent (Raymond \& Turner, 1994). Attracting new customers costs five times as much as retaining current customers. Thus, ensuring a high customer satisfaction level and repeat purchase behavior is critical for business success (Raymond \& Turner, 1994).

A more recent review suggests that the cost of creating a new customer costs four times as much as retaining the existing customers. Thus, the cost is still very high, but not quite as high as it had been in 1994 (McHugh \& Nickels, 2006).

The interplay between the roles of satisfaction and trust in the relationship marketing process indicates the need to pursue future research into a deeper understanding of the communication between the buyer and seller. If the sales rep has a good grasp of the customer's personal feelings concerning his/her comfort level with various communication approaches it could enhance the reception of messages crafted for the customer. This sense of 
concern became visible when the marketplace shifted from transactional selling to customer relationship management. The need for relationship marketing is instrumental for competitive success in the marketplace. In the early stages of the marketing relationship between buyer and seller, the customer only expects a low relational involvement and primarily focuses on overall satisfaction with the product as the governing benchmark. This paradigm shifts over time; however, to a high relational involvement in which the customer uses trust and commitment as the mediators for determining future activities with the selling firm (Rich, 2000).

Actual face-to-face time with a customer could potentially be decreasing as a result of all of the sales automation tools and enhanced communications that are available today. Productivity increases as a result of technology improvements have changed many jobs over the course of the last twenty years. Sales rep positions are no exception to this dynamic.

Many firms have reduced the number of sales reps in their sales force and rely upon technology investments to help build and maintain customer relationships. In fact, researchers are beginning to experiment with electronic interfaces that will mimic the relationship building properties and trust levels that sales reps accomplish. These activities are occurring at a time during which the cost of human capital is at its highest levels (and expected to increase) and the cost of technology is dropping rapidly. Collectively, those statistics underscore the need to better understand when the interpersonal relationship developed with the sales rep is influential in determining customer satisfaction (Jap, S. 2001)

The resulting objective of relationship marketing is to change customer behavior so that loyalty replaces the threat of defection to an ever-increasing horde of competitive products and services. Switching costs presents challenges to both buyer and seller. Mutual trust is by far the most important factor that according to both buyer and sellers, characterize a good relationship. Cooperation refers to the firms' ability to collaborate and work together in a joint fashion toward their respective goals. Essentially, trust and cooperation are considered to be precursors to the development of switching costs in exchange relationships. (Nielson 1996)

The ability of a firm to create and maintain relationships with their most valuable customers results in a competitive advantage over their competitors. One researcher suggests that in order to achieve this, a firm has to master three elements of a market-relating capability. First, a relationship orientation must pervade the mindset values, and norms of the organization. Second, the firm must continuously enhance the knowledge of this customer and distribute this knowledge throughout the company. Third, the key processes must be internally integrated and externally aligned with the corresponding processes of the firm's customers (Day 2000)

From a theoretical approach, to be effective and productive, a sales rep needs to be mindful of all the best practices, sales force automation tools, adaptive selling, customer relationship marketing practices, etc. Additionally, from a daily working relationship perspective, the sales rep needs to understand what the unique requirements are that the individual customer requires.

\section{STUDY RESULTS}

The data in this study is reflective of IT B2B feedback provided in 2005 - 2006 through a telephone survey commissioned by a multinational IT vendor, based in the US. The population that was utilized for this study included 2,766 respondents from the America's group in 2005 and 2,663 respondents from the same group in 2006. These individuals were randomly selected and have responsibility for procurement, finance or information technology (both management and non-management type positions) and range from general staff responsibility to an executive level position. The respondents were not paid for participating in the study. The survey was conducted by a global marketing research firm and they identified themselves as such. The research firm advised the customers that they were conducting a global research study about marketing information technology. The profile of clients by industry is reflected in Table 1. 
Table 1: Profiles of Clients and Industry

\begin{tabular}{|c|c|c|}
\hline Industry Segment & \% Satisfied & Total Respondents \\
\hline All sectors & $85.2 \%$ & 1361 \\
\hline Communications & $89.6 \%$ & 130 \\
\hline Distribution & $82.4 \%$ & 309 \\
\hline Financial Services & $83.8 \%$ & 206 \\
\hline Industrial & $85.4 \%$ & 502 \\
\hline Public Sector & $86 \%$ & 48 \\
\hline Computer Services & $83.3 \%$ & 1298 \\
\hline Small - Medium Business & $85.8 \%$ & 3 \\
\hline
\end{tabular}

Within the America's group, the three US regions were statistically very similar in their satisfaction rating (rating the highest), Canada was slightly lower while Latin America realized the lowest customer satisfaction rating as identified in Table 2 .

Table 2: Breakdown by location

\begin{tabular}{|c|c|c|}
\hline Region & \% Satisfied & Total Respondents \\
\hline Canada & $84 \%$ & 365 \\
\hline US & $85.7 \%$ & 801 \\
\hline - East & $85.7 \%$ & 435 \\
\hline - Central & $84.4 \%$ & 642 \\
\hline - West & $86.6 \%$ & 397 \\
\hline
\end{tabular}

This research was designed to evaluate the value of face-face selling in an industrial sales environment. To evaluate the customer satisfaction ratings, there were 24 questions asked the respondents to determine their actual satisfaction level. Sample questions included:

On a scale of 1-10, how would you rate the provider on the following attributes:

- $\quad$ Is easy to do business with

- Is responsive to customer needs

- Has the expertise to solve a variety of your problems

- Is trustworthy

- Is a market leader ....

In addition to evaluating the channel source (how the customer purchased), the customers were further categorized by product area, specifically: hardware, software and services. The "services" customers had the lowest customer satisfaction while the hardware and software customers were very similar in scope and statistically higher in customer satisfaction than the services customer. From the results provided in this study, it has been determined that customer satisfaction levels are not compromised by engaging in an electronic relationship with the clients versus engaging in a face-face relationship. In fact, the customer satisfaction levels are actually higher in the indirect channel versus the direct channel. The business partner relationship and the indirect relationship essentially are the same relative to customer satisfaction levels.

Loyalty factors were also evaluated with this study and consistent with the results on customer satisfaction levels, loyalty was higher in the indirect client set than the direct client. The specific questions that were asked the customers were as follows: 
- $\quad$ On a 0 to 10 scale where 10 means that you are extremely likely and zero means that you are not at all likely, if you need additional services or solutions in the future, what is the likelihood that you would choose the vendor to provide these services.

- $\quad$ On a 0 to 10 scale where 10 means that you are extremely likely and zero means that you are not at all likely, if you need additional services or solutions in the future, what is the likelihood that you would recommend the vendor to others.

Traditionally, face-face sales interaction between a client and a sales rep has in the past been assumed to be a higher value to the client. Although this way of interacting with a client is more expensive than electronic, large accounts (those that have greater than 1,000 employees) have typically been afforded the availability of this relationship as a result of their size and buying power. With these research results, we are now provided data that suggests that the clients do not perceive any greater value in the face-face versus the indirect. Thus, sales organizations (particularly IT sales) should evaluate the cost benefit of continuing to engage in face-face interaction versus providing a best of breed electronic interface to their clients and hopefully enjoying a more affordable cost structure.

While this analysis is evaluating an industrial IT client, there are some transferable lessons that could be realized within other selling environments. For example, pharmaceutical sales organizations could consider reevaluating the value of having their sales representatives personally calling on physicians. Typically, in these environments, the reps spend quite a bit of time scheduling time with the doctors only to have the appointments cancelled or minimized due to medical emergencies. This can be very frustrating on the part of the representative, especially if it has taken quite a bit of time to schedule time with the doctor, as well as the travel time to the doctor's location. The representatives can be "on call" depending on the doctor's availability and provide insight to the new drugs as well as answer any of the doctor's questions either by phone or email. A good website can also provide an excellent forum for physicians to obtain the information that they need, such as testimonials, government agency reports (such as the Federal Drug Administration), and a section for frequently asked questions (FAQs).

\section{CONCLUSIONS}

Rising labor costs, innovative technology devices and evolving customer preferences are all factors that need to be considered when designing a framework for a solid marketing relationship. Establishing and maintaining solid, long term marketing relationships are vital to the success of a sales representative as well as the firm the representative is employed by (Jap 2000).

Customer satisfaction levels are not compromised by engaging in an electronic relationship with the clients versus engaging in a face-face relationship. The results of this study demonstrate that the customer satisfaction levels are actually higher in the indirect channel versus the direct channel. The business partner relationship and the indirect relationship essentially are the same relative to customer satisfaction levels. Loyalty factors were consistent with the results on customer satisfaction levels. Loyalty was higher in the indirect client set that the direct client.

With the cost of sales rising each year, it is imperative that sales management continually review their cost structures and as well understand their customer's preference on how they prefer to interact with the sales teams.

\section{REFERENCES}

1. Adebanjo, Dotun, (2003), Classifying and selecting e-CRM applications: An analysis-based proposal, Management Decision, 41 (5,6), 570-578

2. Ahearne, Michael, Gruen, Thomas and Cheryl Jarvis, (1999). If looks could sell: Moderation And mediation of the attractiveness effect on salesperson performance. International Journal of Research in Marketing, 16, (September) 269-284

3. Anderson, Erin and Thomas S. Robertson., (1995), Inducing Multi-Line Salespeople to Adopt House Brands, Journal of Marketing, 2 (April), 16 - 31 
4. Ambler, Tim, (2000), Comment: Customer lifetime values - credible, or utterly incredible?, Journal of Targeting, Measurement and Analysis for Marketing, 3 (March), 201-202.

5. Anonymous, (2003), Oracle Announces Enhanced Applications to Drive Sales Effectiveness, $P R$ Newswire, New York, (May).

6. Anonymous, (2001), E-Business Spurs Sales Productivity, PR Newswire, New York, (April).

7. Anonymous, (2000), Web-based pharmaceutical product launch support from NDC Health Information Services Increase Sales Productivity", PR Newswire, New York, (March).

8. Anonymous, (2000), Nortel Networks: NewSouth selects Nortel Networks CRM solution to improve sales productivity, Efficiency, PR Presswire, Coventry, (December).

9. Anonymous, (1995), Relationship marketing: Reaping the benefits of IT, International Journal of Retail \& Distribution Management, 23 (11), 12-14.

10. Anonymous, (2001), Customer Relationship Marketing: Get to know your customers and win their loyalty, Management Research News, 24, (1/2), 73.

11. Anonymous, (2000), E-commerce with the personal touch, Strategic Direction, 16, (6), 13-15.

12. Anonymous, (1988), Increasing Sales Productivity by Getting Salespeople to Work Smarter, Journal of Personal Selling \& Sales Management, 3, (August), $9-19$.

13. Avlonitis, George and Despina Karayanni, (2000), The Impact of Internet use on Business-to Business Marketing, Industrial Marketing Management, 29, 441-459.

14. Bauer, Hans H., Mark Grether, Mark Leach, (2002), Customer Relations through the Internet, Journal of Relationship Marketing, 1, 39.

15. Best Practices Database Online, (2003), Increasing Sales Productivity through Superior Sales Force Performance Management, www.best-in-class.com.

16. Boorom, Michael, Goolsby, Jerry and Rosemary Ramsey, (1998), Relational Communication Traits and Their Effect on Adaptiveness and Sales Performance, Journal of the Academy of Marketing Science, 26, (Winter) 16-30.

17. Bowen, John T., and Stowe Shoemaker, (1998), Loyalty: A strategic commitment, Cornell Hotel and Restaurant Administration Quarterly, 39, (1), 12-26.

18. Business Editors, (2003), Sales Force Effectiveness: Companies Share Winning Tactics for Optimizing Performance, Business Wire, Best Practices LLC (June).

19. Business Editors, (1998), Best Practices, LLC Completes Study into Key Drivers of Sales Force Automation Success, Business Wire, Best Practices LLC (December).

20. Brown, Steven and Robert Peterson, (1994), The Effect of Effort on Sales Performance and Job Satisfaction, Journal of Marketing, 58, (April) 70-80.

21. Byrnes, Thomas, (1996) IBM Training, Manuscript submission to Pace University for course Credit (4 marketing courses) for undergraduate degree, (December).

22. Cahner's Research, (2001) Building a better commerce site: Commerce Functionality and growth to 2001, www.marketresearch.com.

23. Calabro, Sara, (2005), On the Same Page, Sales and Marketing Management, 157 (1), 18.

24. Calciu, Mihai, and Francis Salerno, (2002), Customer value modeling: Synthesis and extension proposals, Journal of Targeting, Measurement and Analysis for Marketing, 11 (2) 124-148.

25. Chaston, Ian, (2000), Relationship Marketing and the Orientation Customers Require of Suppliers, The Service Industries Journal, 20, (3) 147-166.

26. Chonko, Lawrence, Loe, Terry, Roberts, James and John Tanner, (2000), Sales Performance: Timing of Measurement and Type of Measurement Make a Difference, Journal of Personal Selling \& Sales Management, 20, (Winter), 23-36.

27. Churchill, Gilbert, A (1979), A Paradigm for Developing Better Measures of Marketing Constructs, Journal of Marketing Research, 16, (February), 64-73.

28. Claycomb, Cindy and Charles L. Martin, (2002), Building customer relationships: An inventory of service provider's objectives and practices, The Journal of Services Marketing, 16, (7) 615-636.

29. Coulter, Keith S., and Robin A. Coulter, (2002), Determinants of trust in a service provider: The moderating role of length of relationship, The Journal of Services Marketing, 16, (1), 35-51.

30. Cowles, Deborah, (1997), The role of trust in customer relationships: asking the right questions, Management Decision, 35, (4), 273. 
31. Crosby, Lawrence A and Sheree L. Johnson, (2001), Technology: Friend or foe to customer relationships?, Marketing Management, 10, (4), 10-12 .

32. Day, George S., (2000), Managing Market Relationships, Journal of the Academy of Marketing Science, 22, (Winter), 24-30.

33. Davis, Scott and Cathy Halligan, Extending your brand by optimizing your customer relationship, The Journal of Consumer Marketing, 19, (1), 7-12.

34. Dion, Paul and Peter Banting, (2000), Comparisons of Alternative Perceptions of Sales Performance, Industrial Marketing Management, 29, 263-270.

35. Dion, Paul, Easterling, Debbie and Raj Javalgi, (1997), Women in the Business-to-Business Salesforce, Some Differences in Performance Factors, Industrial Marketing Management, 26, 447-457.

36. Dixon, Andrea, Comer, James (2002), Measuring Source-Risk Framing among sales reps, American Marketing Association Educator's Conference, Summer, 327-328.

37. Drucker, Peter, (1988), The coming of the new organization, Harvard Business Review, January-February.

38. Ellis, Debra, (2004), Getting Personal with Relationship Marketing, Catalog Age, 21 (12) 57

39. Farrell, Seonaid and Ralph Hakstian, (2001), Improving Salesforce Performance: A Meta-Analytic Investigation of the Effectiveness and utility of Personnel Selection Procedures And Training Interventions, Psychology \& Marketing, 18, (March) 281-316.

40. Frankwick, Gary, L., Porter, Stephen S and Lawrence A. Crosby, (2001), Dynamics of Relationship Selling: A Longitudinal Examination Of Changes in Salesperson-customer Relationship Status, Journal of Personal Selling \& Sales Management, 2 (Spring), 135-146.

41. Fournier, Susan, Dobscha, Susan and David Glen Mick, (1998), Preventing the premature death of relationship marketing, Harvard Business Review, 76 (n1), 42-50.

42. Garbarino, Ellen, and Mark Johnson, (1999), The different roles of satisfaction, trust, and commitment in customer relationships, Journal of Marketing, 63, (2) 70-88.

43. Geissler, Gary L, (2001), Building customer relationships online: The Web site designers' perspective, The Journal of Consumer Marketing, 18, (6), 488-503.

44. Giulbert, David, Lee-Kelley, Liz and Robin Mannicom, (2003), How e-CRM can enhance customer loyalty, Marketing Intelligence \& Planning, 20 (4,5), 239-249.

45. Gjertsen, Lee Ann, (2002), Platform Reps Emerging as Key Salespeople, American Banker, 167, (October) 10 .

46. Hamble, Matt, (1999), Tools Boost Company's Sales Productivity More Than 20\%, Computerworld Magazine, 37, (September), 24.

47. Health/Medical Writers, (2000), Tools of the Trade: What Pharmaceutical Sales Reps Say They Need to Do Their Best, Business Wire, Scott-Levin's Sales Force Productivity \& Effectiveness Study, (May).

48. Hamblen, Matt, (1999), Tools Boost Company's Sales Productivity More Than 20\%, Computerworld, 9 , (September) 24.

49. Harden, Gary, (2002), E-banking comes to town: Exploring how traditional UK high street banks are meeting the challenge of technology and virtual relationships, Journal of Financial Services Marketing, 6 (4) 323-333.

50. Healy, Marilyn, Hastings, Kathleen, Brown, Les and Michael Gardiner, (2001), The old, the new and the complicated - A trilogy of marketing relationships, European Journal of Marketing, 1 / 2, 182-193.

51. Heide, Jan B. and George John, (1992), Do Norms Matter in Marketing Relationships?, Journal of Marketing, 2, (April), 32-48.

52. Hochwald, Lambreth, (1997), Hold The Phone, Sales \& Marketing Management, 5, (May) 72-78.

53. IBM Market Intelligence Survey, (2003) Sales Rep Time Activity Report, June 2003.

54. Jap, Sandy D., (2001), The Strategic Role of the Salesforce in developing customer satisfaction across the relationship Lifecycle, Journal of Personal Selling \& Sales Management, 2, (Spring), 95-108.

55. Johnson, Julie T., Barksdale, Hiram, C. and James S. Boles, (2001), The strategic role of the salesperson in reducing customer defection in business relationships, The Journal of Personal Selling and Sales Management, 21, (2), 123-135.

56. Kahle, Dave, (2000), Concentrating on Sales Productivity, Agency Sales Magazine, 4, (April) 61 - 62.

57. Kern, Richard and George J. Frederick, (1986), Survey of Selling Costs: Onward And Ever Upward, Sales and Marketing Management, 3, (February), 10. 
58. Landeros, Robert, Reck, Robert and Richard Plank, (1995), "Maintaining Buyer-Supplier Partnerships", Journal of Supply Chain Management, 31, (Summer) 3-11.

59. Lupton, Robert, Weiss, John and Robin Peterson, (1999), "Sales Training Evaluation Model (STEM)", Industrial Marketing Management, 28, 73-86.

60. Mann, Leon, Samson, Danny and Douglas Dow, (1998), A Field Experiment on the Effects of Benchmarking and Goal Setting on Company Sales Performance, Journal of Management, 24, 73-96.

61. Marchetti, Michelle, (2003), Free Up Your Reps' Selling Time, Sales \& Marketing Management, 5 (May) 16.

62. MacKenzie, Scott, Podsakoff, Philip and Gregory Rich, (2001), Transformational and Transactional Leadership and Salesperson Performance, Journal of the Academy of Marketing Science, 29, (Spring) 115134.

63. Marketing Monthly online, www.marketingmonthly.com, The Basics - Marketing 101, Chapter: Disadvantages to Personal Selling.

64. Masciarelli, James P, (1998), Are you managing your relationships?, Management Review, 87, (4), 41-46.

65. McIntyre, Faye S, Thomas, James L, Tullis, K. J. and Joyce A. Young, (2004), Assessing effective exchange relationships: an exploratory examination, Journal of Marketing Theory and Practice, 12 (1), 3648.

66. Mitchel, James, (2002), Comparison of sales performance across financial services sectors, Journal of Financial Services Marketing, 7 (November) 178-185.

67. Morgan, Robert M, Shelby D. Hunt, (1994), The Commitment-Trust Theory of Relationship Marketing, Journal of Marketing, 7, 20-28.

68. Moursund, D. (1983), Computer Literacy, Computer Teacher, 10(8), 3-4.

69. Nickels, William G., McHugh, James M. and McHugh, Susan M, Understanding Business Eighth Edition, 2005.

70. Nielson, Charles S., (1996), An empirical examination Of switching cost investments in business-tobusiness marketing relationships, Journal of Business \& Industrial Marketing, 6, 38-60.

71. Paas, Leonard and Ton Kuijlen, (2001), Towards a General Definition of customer relationship management, Journal of Database Marketing, 1, (September), 51-60.

72. Parker, Betty and Richard Plank, (2000), A Uses and Gratifications Perspective on the Internet As a New Information Source, American Business Review, 18, (June) 43-49.

73. Pilling, Bruce, Donthu, Naveen and Steve Henson, (1999), Accounting for the Impact of Territory Characteristics on Sales Performance: Relative Efficiency as a Measure of Sales Person Performance, Journal of Personal Selling \& Sales Management, 19, (Spring) 35-45.

74. Plank, Richard and David Reid, (1994), The Mediating Role of Sales Behaviors: An Alternative Perspective of Sales Performance and Effectiveness, Journal of Personal Selling \& Sales Management, 14, (Summer) 43-55.

75. Plank, Richard and Deborah Francis (2001), Does Reverse Marketing Reduce Conflict in Buyer-Seller Relations, American Business Review, 19, (January) 76-83.

76. Plank, Richard, Reid, David and Ellen Bolman Pullins, (1999), Perceived Trust in Business To Business Sales: A New Measure, Journal of Personal Selling \& Sales Management, 19, (Summer) 61-71.

77. Plank, Richard and Joel Greene, (1996), Personal construct psychology and personal selling Performance, Journal of Marketing, 30, 25-48.

78. Plank, Richard and David Reid, (1996), Difference between success, failure in selling, Marketing News, 30, (November) 6-14.

79. Raymond, Maryann and John F. Turner, Jr. (1994), Maintaining Customer Relationships in Direct Sales: Stimulating Repeat Purchase Behavior, Journal of Personal Selling \& Sales Management, 4, (Fall), 67-76.

80. Rich, Michael K., (2000), The Direction of Marketing Relationships, Journal of Business \& Industrial Marketing, 2/3, 170-179.

81. Ricks, James and John Fraedrich, (1999), The Paradox of Machiavellianism: Machiavellianism May Make for Productive Sales but Poor Management Reviews, Journal of Business Ethics, 20, 197-205.

82. Sales \& Marketing Management Magazine, www.salesandmarketing.com, Online survey 2000,

83. Sales \& Marketing Management Online www.salesandmarketing.com, The Cost of Doing Business. 
84. Schoenbachler, D. D. and Geoffrey Gordon, (2002), Trust and customer willingness to provide information in database-driven relationship marketing, Journal of Interactive Marketing, 16 (3), 2-16.

85. Schulman, Peter, (1999), Applying Learned Optimism to Increase Sales Productivity, Journal of Personal Selling \& Sales Management, 1, (Winter), 31 - 37.

86. Schultz, Robert J. and Kennth R. Evans, (2002), Strategic collaborative communication by key account representatives, Journal of Personal Selling \& Sales Management, 1, (Winter), 23-31.

87. Seligman, M.E.P, (1975), Helplessness: On depression, development and death.

88. Senge, Peter, (1990), The Fifth Discipline - The Art \& Practice of The Learning Organization, 4, 15, 219.

89. Sharma, Arun, Levy, Michael and Ajith Kumar, (2000), Knowledge Structures and Retail Sales Performance: An Empirical Examination, Journal of Retailing, 76, (Spring) 53-69.

90. Sheth, Jagdish, Sisodia, Rajendra and Arun Sharma, (2000), The antecedents and consequence of customercentric marketing, Academy of Marketing Science, 28, (1), 55-67.

91. Shoemaker, Mary E., (2001), A Framework for Examining IT-Enabled Market Relationships, Journal of Personal Selling \& Sales Management, 2, (Spring), 177-185.

92. Simonson, M.R., Maurer, M., Montag-Torardi, M. \& Whitaker, M., (1987), Development Of a standardized test of computer literacy and a computer anxiety index, Journal of Educational Computing Research, 3(2), 231-247.

93. Smith, Brock, (1998), Buyer-seller relationships: Bonds, relationship management, and sex type, Revue Canadienne des Sciences de l'Administration, 15, (1) 76-93.

94. Starkey, Michael and Neil Woodcock, (2002), CRM systems: Necessary, but not sufficient, REAP the benefits of customer management, Journal of Database Marketing, 3, (March), 267-275.

95. Steinman, Christine, Rohit Deshpande and john Farley, (2000), Beyond market orientation: When customers and suppliers disagree, Academy of Marketing Science, 28, (1), 109-120.

96. Stewart, Greg, (1996), Reward Structure as a Moderator of the Relationship Between Extraversion and Sales Performance, Journal of Applied Psychology, 1 (June) 619-627.

97. Sujan, Harish, Weitz, Barton A and Nirmalya Sujan, (1994), Learning Orientation, Working Smart, and Effective Selling, Journal of Marketing, 3, (July), 39 - 52.

98. Sweeney, Stephen and Thomas H. Rogers, Jr., (2002), Get interactive with e-sales training, Medical \& Marketing Media, 11 (November) 51-58.

99. Tax, Stephen S., Brown, Stephen W., and Murali Chandrashekaran, (1998), Customer evaluations of service complaint experiences: Implications for relationship marketing, Journal of Marketing, 62, (2), 6077.

100. Torrence, Corey, (2001), Shaping the future of Relationship Marketing, Direct Marketing, 63 (11), 62-65.

101. Treasure, Julian, (2002), A relationship's success relies on conversation, Marketing, 5/23/2002, 22.

102. Turner, M.G., Sweany, W.N., \& Husman, J. (2000), Development of the computer literacy Measure, Journal of Educational Computer Research, 22(1), 37-54.

103. Vasu, M.L., \& Vasu, E.S. (1989), In defense of Computer literacy, Social Science Computer Review, 7(1), 27-35.

104. Weitz, Barton A. and Kevin D. Bradford, (1999), Personal Selling and Sales Management: A Relationship Marketing Perspective, Journal of the Academy of Marketing Science, 2, (Spring) 241 - 254.

105. Wiesenhofer, Hildegard, Ellis-Chadwick, Finoa and Peter McHardy, (2002), Online customer relationships in the European financial services sector: A cross-country investigation, Journal of Financial Services Marketing, 6, (4), 333-346.

106. Xu, Yurong, Yen, D.C., Binshan, L, and David Chou, (2002) Adopting customer relationship management technology, Industrial Management and Data Systems, 102 (8, 9), 442-453. 